\title{
KNOWLEDGE, ATTITUDE, REASONS OF NOT ACCEPTANCE AND DISCONTINUATION OF CONTRACEPTIVE METHODS AMONG WOMEN ATTENDING OPD OF TERTIARY HEALTH CARE CENTER
}

\author{
Nisha Mandloi ${ }^{1}$, Khushboo Verma ${ }^{2}$
}

${ }_{1}^{1}$ Assistant Professor, Department of Obstetrics and Gynaecology, M. G. M. Medical College, Indore, Madhya Pradesh.

${ }^{2}$ Assistant Professor, Department of Obstetrics and Gynaecology, People's Medical College, Bhopal, Madhya Pradesh.

\section{ABSTRACT}

AIM

Aim of our study was to assess the knowledge and attitude regarding contraceptive methods and practices of contraception among women of reproductive age group attending Sultania Zanana Hospital OPD.

\section{OBJECTIVE}

To study the reasons of not acceptance and discontinuation of different contraceptive methods.

\section{MATERIAL AND METHOD}

The study population was women of reproductive age 15-45 yrs. reporting to OPD for whatsoever causes and representing the surrounding area of Sultania Zanana Hospital, Bhopal. Sample size is based on prevalence of use of contraceptives methods. The estimated sample size was 396, the present study was conducted on 3200 women, which was sufficient to meet the objectives of the study. During the study period eligible women were selected and interviewed. Participation of the selected women was voluntary after explaining the purpose of the study.

\section{RESULT}

In our study majority of women respondents (45\%) were in the age group of 20-25yr. In present study, knowledge of contraceptives was found to be almost universal (98\%). It is noticeable that $83.59 \%$ respondents showed a positive attitude toward family planning. In our study, most common reason for discontinuation of IUD was wanting a child (27\%) followed by back pain (21\%) and most common reason for discontinuation of OC pills in spite of awareness was wanting a child (44\%). Among the nonusers, $18.26 \%$ did not intend to use them in the future with the main reason being completed their family size and $50.39 \%$ were pregnant out of which $12.6 \%$ were using before pregnancy and most common reason for not using was desire for male child in about $33.28 \%$ cases.

\section{CONCLUSION}

In the our study knowledge of contraception is almost universal, mostly women shows positive attitude toward family planning and most common reason of non-acceptance or discontinuation of contraceptive was wanting a child specially a male chid, which highlight a strong preference for male child in the Indian society.

\section{KEYWORDS}

Contraceptives, Contraceptive Discontinuation, Contraceptive Not Acceptance.

HOW TO CITE THIS ARTICLE: Nisha Mandloi, Khushboo Verma. "Knowledge, Attitude, Reasons of not Acceptance and Discontinuation of Contraceptive Methods among Women Attending OPD of Tertiary Health Care Center." Journal of Evolution of Medical and Dental Sciences 2015; Vol. 4, Issue 102, December 21; Page: 16723-16729, DOI: 10.14260/jemds/2015/2503

\section{INTRODUCTION}

Population growth has long been a concern for the Government of India. India has a lengthy history of making explicitly population policies. According to the 2011 census, the population of India is $1,210,193,422$. India supports $17.54 \%$ of the world population, while it forms only $2.4 \%$ of the total world area, i.e. it is the second most populous country after China. Women of reproductive age group (15-45 years) make up approximately 248 million population. The current fertility level of a woman in India is 2.62 births per women and Madhya Pradesh has an average fertility level of 3.1 (2011).(1,2,3,4)

Financial or Other, Competing Interest: None.

Submission 07-12-2015, Peer Review 08-12-2015,

Acceptance 14-12-2015, Published 18-12-2015.

Corresponding Author:

Dr. Khushboo Verma,

C/o. Ashok Kumar Verma, I. A. S,

D-21, Upant Nagar, Char Imli,

Bhopal-462001.

E-mail: khushboobpl31@gmail.com

DOI:10.14260/jemds/2015/2503
India's current demographic phase is characterized by a high fertility rate and moderate mortality rate realizing that high population growth is inevitable during the initial phases of demographic transition and the urgent need to accelerate the pace of transition, India became the first country to formulate a national family planning programmed in 1952 . The objective of policy was "Reducing birth to the extent necessary to stabilize the population at a level consistent with requirement of national economy." $[1,2,5,6]$ The National policy 2000 had set a goal that India will have to achieve the replacement level of fertility by 2010, but achievement of goals have been limited by the diversity of religion, poverty, employment, literacy, public and private health care facilities, urbanization, malnutrition, per capita income, sex of previous child. $(1,7)$

\section{MATERIAL AND METHODS}

The present study entitled "Contraceptive Knowledge, Attitude and Practice among Women attending OPD of Sultana Zanana Hospital" was an analytical cross-sectional study carried out in the Department of Obstetrics and Gynaecology, Gandhi Medical College and Sultania Zanana Hospital, Bhopal 
from $1 / 8 / 12$ to $31 / 7 / 13$. Permission from the ethical committee was sought before the starting of the study. No surgical intervention, drug administration or examination procedure was carried out during the study period. The informed consent of all the subjects was taken before starting interview. Confidentiality of the interview was maintained by coding. Data was collected through a pre-designed pretested questionnaire in women attending OPD.

The study population was women of reproductive age 15-45 yrs. reporting to OPD for whatsoever causes and representing the surrounding area of SZH. Sample size is based on prevalence of use of contraceptives methods. The estimated sample size was 396. The present study was conducted on 3200 women, which was sufficient to meet the objectives of the study. During the study period, eligible women were selected and interviewed. Participation of the selected women was voluntary after explaining the purpose of the study. A predesigned and pretested Questionnaire developed was filled. To protect confidentiality of the respondent, names were not written.

\section{Questionnaire}

Sociodemographic characteristics of the interviewed women attending SZH OPD.

1. Name W/o.

2. Religion.

3. Address:

4. Rural/Urban.

5. Type of Family: Joint/Nuclear.

6. Age in years.

7. Parity.

8. Education.

9. Age at Marriage.

\section{Knowledge and Awareness regarding Contraception}

- Natural Methods.

- Condoms.

- OCP.

- IUCD.

- Injectables.

- Tubal ligation.

- $\quad$ Others.

\section{Source of Knowledge}

- Media.

- Health personnel.

- Social circle.

- Education.

\section{Attitude for Contraception:}

Thinking that benefits of modern contraceptives outweigh negative effects, desire to know more on modern contraceptives would recommend use of modern contraceptives to a friend if not current user of modern contraceptives, if intends to use them in future husband approve modern contraceptives.

\section{Practices of Contraception}

a) Contraceptive Methods in use

- Barrier method (Condom).

- Oral Pills.

- IUCD.

- Injectables.
- Tubal ligation.

- Others.

b) Reasons for using Contraceptives

- Completed their families.

- Spacing of birth.

- Improvement of health.

- Economical problems.

c) Reasons for not using Contraceptives

- Want child.

- Tubal Ligation.

- No guidance.

- Opposition from home.

- Breast feeding

- Hysterectomy.

- Not having sex.

- Worry about side effects.

- No knowledge.

- Menopausal.

- Religion.

- No knowledge about source.

- Harmful to health.

- Husband away.

- Not giving any answer because of shyness and hesitation.

d) Reasons for Discontinuation of Contraceptives Method

- Want male child.

- Want female child.

- Bleeding.

- Back pain.

- White discharge.

- Abdominal pain.

- Spontaneous expulsion.

- Failure.

- Headache.

- Irregular bleeding.

- Weight gain.

- Weight loss.

- Fatigue.

- Backache.

- Nausea, vomiting.

- Increase heart beats

- Pains in the reproductive organ.

Utilization of family planning methods to birth order.

\section{RESULT AND ANALYSIS}

In our study age distribution among the respondents was: $5.53 \%, 45.13 \%, 26.03 \%, 11.78 \%, 6.94 \%, 4.49 \%$ in the age category of 15-19 years, 20-24 years, 25-29 years, 30-34 years, 35-39 years, 40-45 years, respectively. Majority of women, i.e. $45 \%$ of the total were in the age group of $20-24$ and $5 \%$ women were in the age group 40-45 yrs. Hence, mean age group is 25 year. (Table-1).

In our study majority of women, i.e. 2870(89.77\%) belonged to urban area followed by rural $330(10.23 \%)$; majority of women belonged to joint family, i.e. 2187(68.35\%) followed by nuclear family $1013(31.65 \%)$ and majority of women belonged to Muslim community, i.e. 1778(55.57\%) followed by Hindu 1422(44.43\%). (Table-2). 
In the present study, about $13.33 \%$ of counseled women had received no schooling; $14.17 \%, 46.45 \%, 24.62 \%$ of counseled women had enrolled in primary, secondary school and high school respectively. Only about $1 \%$ of counseled women had entered university and $0.43 \%$ were professional. (Table-3).

In our study, the knowledge of contraceptives was found to be universal: $98.65 \%$ of respondents had heard about contraceptives regardless of educational level and socioeconomic status. All except 43 woman (2.34\%) had heard about contraceptives and knew at least one modern method. Though this study reveals high knowledge of contraceptives among respondents, the knowledge varies from one method to another. The most popular methods known by respondents were the condom, tubectomy and pill contraception, which accounted for $91 \%, 93 \%$ and $58 \%$ respectively. The IUCD (38\%) was the fourth most popular method cited by respondents followed by the injectable contraceptives $11 \%$. In addition about $1 \%$ of respondents know other alternatives, which included traditional methods such as abstinence and withdrawal; $57.75 \%$ respondents intended to use them in future; among those who were willing most (82.6\%) wanted sterilization for themselves as the permanent method. As for the temporary methods, $16.3 \%$ wanted to use an IUCD, $68 \%$ wanted to use condom and 2\% OCP. (Table-4).

This study also found that information about family planning was mostly obtained through Media (58.15\%) followed by neighbors, friends and relatives (45.30\%) and then health personal (31\%) and education were last (5.83\%). (Table-5).

It is noticeable that $83.59 \%$ respondents showed a positive attitude toward family planning and $45.68 \%$ husbands of the women counseled had approved contraceptives. Almost $24.56 \%$ desire to know more on modern contraceptives; $21.43 \%$ women would recommend use of modern contraceptives to a friend; $57.75 \%$ intended to use them in future; among those who were willing most $(82.6 \%)$ wanted sterilization for themselves as the permanent method. As for the temporary methods, $16.3 \%$ wanted to use an IUCD; $68 \%$ wanted to use condom and $2 \%$ OCP. Though almost all $84 \%$ respondents demonstrated positive attitudes in discussing family planning, some respondents $(14.41 \%)$ disapproved of unmarried or single women or old women discussing contraception. (Table-6).

About $1225(38.28 \%)$ of respondents had used some contraceptive method and among the users, the majority were condom users (53\%) followed by IUCD method (18\%), tubectomy $18 \%$ and only about $10 \%$ of respondents said that they were using pill as a method of family planning. None of the current users were using male sterilization and the traditional natural methods were used by only $1 \%$ of the respondents. Among all respondents, 39\% were using some method of modern contraceptives and 61\% were not practicing any method. Most common reason for accepting family planning methods was spacing, i.e. $78.28 \%$ and $4 \%$ of the respondents discontinued. (Table-7).

In our study most common reason for discontinuation of IUD was wanting a child (27\%) followed by back pain $21.21 \%$ and increased irregular bleeding $18.18 \%$, white discharge $15.15 \%$ and abdominal pain, spontaneous expulsion and failure. Most common reason for discontinuation of OC pills in spite of awareness was wanting a child, i.e. $44 \%$ followed by
$31.25 \%$ who were not giving any reason and other most important reasons were forgetting to take the pill, failure and irregular bleeding was answered by only 1 women. (Table-8).

In our study among the non-users, $18.26 \%$ did not intend to use them in the future with the main reason being completed their family size and $50.39 \%$ were pregnant out of which $12.6 \%$ were using before pregnancy and most common reason for not using was desire for male child in about $33.28 \%$ cases which highlight a strong preference for male child in the Indian society.

Almost $17.41 \%$ of non-users were concerned about using modern methods due to their rumoured side effects; $2.44 \%$ did not use it because of hesitency. Other common reasons was no guidance $5.98 \%$, breast feeding $4.86 \%$, abstinence $3.74 \%$, inadequate and improper knowledge of the contraceptives methods $1.42 \%$ and against religion of the family was in $1.97 \%$. (Table-9).

\section{DISCUSSION}

In our study majority of women respondents (45\%) were in the age group of 20-25yr. In similar studies conducted by Patel M et al. (2001.[8], Mustafa R et al. (2005).[9], N Saluja et al. (2008-09).[10], J Lwelamira et al. 2009.[11] majority of the women were in age group of 25-30yr, 25-35yr, 20-30yr respectively. This may be because contraceptive use varies with age, usually reaching peak around 20-25 yr. and then declining.

In present study majority of women respondents (89.77\%) belonged to urban area. Contraceptives acceptance was found more in urban population $(38.78 \%$,) because urban population were more likely to adopt contraceptives methods as they were having better health services, education system and availability of contraceptives methods. According to NFHS 3.[2,3,4] rural women have higher unmet need than urban women for both spacing and limiting. According to DLHS 3.[12] $62.3 \%$ of urban population used contraceptive methods as compared to $56.3 \%$ of rural population.

In present study, knowledge of contraceptives was found to be universal; $98 \%$ of respondents had heard about contraceptives regardless of educational level and socioeconomic status. All except $2 \%$ had heard about contraceptives and knew at least one modern method.

This study revealed high knowledge of contraceptives among respondents and this helped people in adopting contraceptive methods. The findings were similar to prevalence of knowledge (98.2\% in men and $97.7 \%$ in women) reported by NFHS-III (2005-06).[2,3,4] \% Lwelamira 2009.[11] (98\%) and slightly lower than the findings of Takkar et al.[13] (100), SREYTOUCH1 et al. 2008.[14] (99\%), but higher than $40 \%$ to $45 \%, 78.8 \%, 75.0 \%, 73.5 \%, 81 \%, 82.2 \%, 90 \%$ and $95.0 \%$ as reported by Sajid A Malik et al.[15], Jain et al.[16], Kumar et al.[17], Chandhick et al.[18], Mustafa R et al.[9], Srivastava Reena et al..19], SK Kaushal.[20] and Patro et al.[21] respectively.

In present study, knowledge of contraceptives found to be universal: $98.65 \%$ of respondents. The most popular methods known by respondents were the tubectomy, condom, pill, IUCD and injection, which accounted for 93\%, 91\%, 54\%, $38 \%$ and $11 \%$ respectively. Only $1 \%$ of respondents knew traditional methods, such as abstinence and withdrawal. 
This shows that there is a need to widen the knowledge of other methods of contraception to provide people with wide basket of choices. In the study done by Srivastava Reena et al. (2002-03).[19] most commonly known methods were tubectomy (82.2\%), IUCD(61.2\%), ОCP(60.5\%) condoms (53.7\%). According to S K Kaushal et al. 2005.[20] the most commonly known methods were tubectomy, OCP, IUCD, condom followed by injection indicated by $98.6 \%, 97.1 \%$, 92.5\%, 90.4\%, 8.6\% respondents, respectively.

Sajid A, Malik S 2008.[15] showed that women sterilization was more popular method among the women who reported knowledge of contraceptive methods John Mao 2007.[22] observed that $48 \%$ of the respondents had the knowledge of tubectomy.

This study also found that information about family planning was mostly obtained through media (58.15\%) followed by neighbor, friend and relatives (45.30\%) and then health personal (31\%) and education was last (5.83\%).

This showed that there is a need to increase the health worker and paramedical staff with proper training, so that they motivate people regarding family planning practices.

According to NFHS 3 more than three in five women heard or saw a family planning message, most often on television or radio similar studies constructed by Mustafa R et al. 2005.[9] (64\%), Roumi Deb 2006 -07.[23] showed mass media as an important source of information .

SREYTOUCH 2008.[14] (56\%), Deepa H Valenkar.[24] et al. $2009(53.7 \%)$ studied that health personal was the most common source of information. Srivastava Reena, et al. 200203.[19] observed that the important source of knowledge about contraceptive methods was family members, friends and television. N Saluja et al.[10], Mgabo et al. 2010.[25] found that most common source of knowledge for all couples in general was the "Exposure to family planning messages" (72.0\%) followed by discussion with doctors and other health care workers (42.6\%).

Present study showed attitude as the most difficult part to measure, as it is characterized in a very abstract way. It is noticeable that $83.59 \%$ respondents showed a positive attitude toward family planning. According to women counselled, $45.68 \%$ husbands had approved contraceptives. Almost $24.56 \%$ desired to know more on modern contraceptives; $21.43 \%$ women would recommend use of modern contraceptives to a friend and some respondents $(14.41 \%)$ disapproved of unmarried or single women or old women discussing contraception.

Srivastava Reena et al. 2002-03.[19] (82.9\%), SK Kaushal et al. 2005.[20] (42.9\%) Mustafa $\mathrm{R}$ et al. 2005.[9] (76\%) SREYTOUCH et al. 2008.[14] (52.8\%), J Lwelamira et al. 2009.[11], Sajid AS 2008-09.[15] 54\%, John Mao.[22] (56\%) found a positive attitude towards contraceptive methods and approved family planning in future. Studies done by Gaur DR 2008.[26] A Kansal et al. 2005.[27] showed that $78 \%$ and $74 \%$ of husbands approved the use of contraceptive methods at the time of survey.[28,29] However, husband support for family planning was significantly higher in a Jordanian study.[30]

Attitude of husband was found to be an important predictor for contraception use. A negative attitude of husband towards contraceptive methods was observed in studies conducted by Mustafa R et al. 2005.[9] (59\%), J Lwelamira 2009.[11] (65.8\%).
It also has been observed in other studies in Africa (Tuloro et al. 2006; Nwankwo and Ogueri, 2006; Igwegbe et al. 2009; Burke and Ambasa-Shisanya, 2011; Mathe et al. 2011).[31,32,33,34,35] In present study discontinuation of contraceptive methods were $4 \%$ among user. Most common reasons for discontinuation of IUD is wanting a child, $27 \%$ followed by back pain, $21.21 \%$ and increased irregular bleeding $18.18 \%$, white discharge $15.15 \%$ and abdominal pain, spontaneous expulsion and failure $6.06 \%$ each.

Most common reason for discontinuation of OC pills in spite of awareness was wanting a child, i.e. $44 \%$ followed by $31.25 \%$ who were not giving any reason and other most important reasons were forgetting to take, failure, irregular bleeding (6.25\% each).

According to NFHS $3 .[2,3,4]$ discontinuation rates for temporary methods were high: 39 percent of users of temporary methods discontinue use within 12 months of initiating use. About half of pill users discontinue use within the first year of adopting the method Deepa H Valenkar et al.[24] studied that the important reason for discontinuation of family planning was mother's desire for children $(61.1 \%$ desire for male child, while $22.2 \%$ had desire for female child).

In contrast to our study J Lwelamira et al. 2009.[11] in their study found the most important reason for discontinuation of contraceptives method was side effects (56\%). Of the side effects reported, irregular bleeding and abdominal pain were the main side effects ever experienced being $64.3 \%$ and $32.1 \%$ respectively. SK Kaushal et al. 2005.[20] in their study found that most common reasons observed for contraceptive defaulter were unavailability (30.88\%).

Roumi Deb 2006-07.[23] et al. in their study found that more than one-third women either do not like the existing methods or find them difficult to use.

Data from NFHS 3 shows that among those who discontinued use at the time of survey, $26 \%$ reported side effect other method related concern as reason for discontinuing use. In present study, couples not practicing contraception were $61 \%$ and was higher as compared to other studies which showed $55 \%$ and $44.6 \% .{ }^{[36,37]}$ Fertility related reason, i.e. need more children (29\%), partner's opposition (8\%) and fear of side effects (18\%) were the reasons found for non-use of contraception. Reasons for non-use of contraceptives have varied in magnitude in different studies Fertility related reasons were found as main reasons by SREYTOUCH et al.[14] (28.4\%) Das et al. (38.9\%).[38] Vaidya et al. (17.8\%).[39] Chandhick et al.[18] (34.6\%), Khokhar et al. (30.7\%).[40] and N Saluja et al. 2008-09.[10] (45.1\%) respectively.

Other common reasons in our study were no guidance $5.98 \%$, breast feeding, abstinence, inadequate and improper knowledge of the contraceptives methods $3.03 \%$, religion of the community $1.97 \%$, hesitation. Among the non-users, $18.26 \%$ did not intend to use them in the future with the main reason being completed their family size and 55\% were pregnant. According to NFHS 3, among currently married women only $29.4 \%$ participated in householder decision.Srivastava Reena et al. 2002-03 (11.4\%), Mitali G et al. 2011 (80.4\%) showed the most common reason was fear of side effect. Other reasons for not accepting contraceptive methods were: Lwelamira $2009 .{ }^{14}$ (71\%) showed that the final decision was to be done by husband Anju et al.[41] 
Roumi Deb 2006 -07.[19] found opposition from family as the main reason, Mitali G et al. 2011 "Forget to take" (7.6\%) and "hesitation" (Jain et al.).[16]

\section{CONCLUSION}

In our study knowledge of contraception is almost universal, mostly women shows positive attitude toward family planning and most common reason of non-acceptance or discontinuation of contraceptive was wanting a child, specially a male chid , which highlight a strong preference for male child in the Indian society.

\begin{tabular}{|c|c|c|c|}
\hline $\begin{array}{c}\text { Sl. } \\
\text { No. }\end{array}$ & $\begin{array}{l}\text { Age in } \\
\text { Years }\end{array}$ & Number & Percentage \\
\hline 1 & $15-19$ & 174 & 5.53 \\
\hline 2 & $20-24$ & 1452 & 45.17 \\
\hline 3 & $25-29$ & 833 & 26.13 \\
\hline 4 & $30-34$ & 374 & 11.78 \\
\hline 5 & $35-39$ & 221 & 6.94 \\
\hline \multirow[t]{2}{*}{6} & $40-45$ & 146 & 4.49 \\
\hline & Total & 3200 & $100 \%$ \\
\hline \multicolumn{4}{|c|}{$\begin{array}{c}\text { Table 1: Showing age distribution } \\
\text { of respondents interviewed }\end{array}$} \\
\hline
\end{tabular}

\begin{tabular}{|c|c|c|c|}
\hline $\begin{array}{c}\text { Sociodemographic } \\
\text { Profile }\end{array}$ & Category & No. & Percentage \\
\hline \multirow{2}{*}{ Residence } & Rural & 330 & 10.23 \\
\cline { 2 - 4 } & Urban & 2870 & 89.77 \\
\hline \multirow{2}{*}{ Religion } & Hindu & 1422 & 44.43 \\
\cline { 2 - 4 } & Muslim & 1778 & 55.57 \\
\hline \multirow{2}{*}{ Type of Family } & Nuclear & 1013 & 31.65 \\
\cline { 2 - 4 } & Joint & 2187 & 68.35 \\
\hline \multirow{2}{*}{ Education } & Illiterate & 451 & 14.09 \\
\cline { 2 - 4 } & Literate & 2749 & 84.91 \\
\hline \multirow{2}{*}{ Table 2: Showing distribution of } \\
respondents according to residence \\
\hline
\end{tabular}

\begin{tabular}{|c|c|c|}
\hline Education Status & No. & \% \\
\hline Illiterate & 451 & $14.09 \%$ \\
\hline Primary & 454 & $14.17 \%$ \\
\hline Secondary & 1487 & $46.45 \%$ \\
\hline Higher Secondary & 788 & $24.62 \%$ \\
\hline Graduate & 32 & $1 \%$ \\
\hline Professional & 14 & 00.43 \\
\hline Total & $\mathbf{3 2 0 0}$ & $\mathbf{1 0 0}$ \\
\hline $\begin{array}{c}\text { Table 3: Showing distribution of } \\
\text { respondents according to education }\end{array}$ \\
\hline
\end{tabular}

\begin{tabular}{|c|c|c|c|}
\hline & Category & $\begin{array}{c}\text { No. of } \\
\text { Respondent }\end{array}$ & $\begin{array}{c}\text { In } \\
\text { Percentage }\end{array}$ \\
\hline \multirow{2}{*}{$\begin{array}{c}\text { Awareness } \\
\text { about } \\
\text { contraceptives } \\
\text { methods }\end{array}$} & Yes & 3157 & $98.65 \%$ \\
\cline { 2 - 4 } & No & 43 & $2.35 \%$ \\
\hline \multirow{4}{*}{$\begin{array}{c}\text { Awareness } \\
\text { about different } \\
\text { contraceptive } \\
\text { methods }\end{array}$} & Condom & 2856 & $91.41 \%$ \\
\cline { 2 - 4 } & OC Pills & 1850 & $58.59 \%$ \\
\cline { 2 - 4 } & IUCD & 1204 & $38.13 \%$ \\
\cline { 2 - 4 } & Injection & 2987 & $93.34 \%$ \\
\cline { 2 - 4 } & $\begin{array}{c}\text { Natural } \\
\text { methods }\end{array}$ & 359 & $11.22 \%$ \\
\hline \multicolumn{3}{|c|}{ Table 4: Distribution of respondents according to } \\
Awareness about contraceptives methods
\end{tabular}

\begin{tabular}{|c|c|c|}
\hline Source of Knowledge & Cases & \% \\
\hline Media & 1836 & $58.15 \%$ \\
\hline Health personal & 976 & $30.92 \%$ \\
\hline $\begin{array}{c}\text { Neighbor, friends and } \\
\text { relatives }\end{array}$ & 1430 & $45.30 \%$ \\
\hline Education & 577 & $18.03 \%$ \\
\hline $\begin{array}{c}\text { Table 5: Distribution of respondents according to source } \\
\text { of knowledge of contraceptives methods }\end{array}$ \\
\hline
\end{tabular}

\begin{tabular}{|c|c|c|}
\hline Variable & Frequency & \% \\
\hline $\begin{array}{c}\text { Approval of contraceptives by } \\
\text { women }\end{array}$ & 2675 & 83.59 \\
\hline $\begin{array}{c}\text { Husband approve modern } \\
\text { Contraceptives }\end{array}$ & 1462 & 45.68 \\
\hline $\begin{array}{c}\text { Thinking that benefits of modern } \\
\text { contraceptives outweigh negative } \\
\text { effects }\end{array}$ & 1034 & 32.31 \\
\hline $\begin{array}{c}\text { Desire to know more on modern } \\
\text { contraceptives }\end{array}$ & 786 & 24.56 \\
\hline $\begin{array}{c}\text { Would you recommend use of } \\
\text { modern contraceptives to a friend }\end{array}$ & 656 & 21.43 \\
\hline $\begin{array}{c}\text { If not current user of modern } \\
\text { contraceptives, if intends to use } \\
\text { them in future }\end{array}$ & 1848 & 57.75 \\
\hline $\begin{array}{c}\text { Table 6: Distribution of respondents by information } \\
\text { related to attitude towards modern contraceptives }\end{array}$ \\
\hline \multicolumn{2}{|c|}{}
\end{tabular}

\begin{tabular}{|c|c|c|c|}
\hline Variable & Category & $\begin{array}{c}\text { Frequenc } \\
y\end{array}$ & $\begin{array}{c}\text { Percen } \\
\text { t (\%) }\end{array}$ \\
\hline \multirow{2}{*}{$\begin{array}{l}\text { If used modern } \\
\text { contraceptives } \\
(n=3200)\end{array}$} & Yes & 1225 & $38.28 \%$ \\
\hline & No & 1975 & $61.72 \%$ \\
\hline \multirow{6}{*}{$\begin{array}{c}\text { Method(s) ever } \\
\text { used* } \\
(n=1225)\end{array}$} & Condom & 646 & $52.65 \%$ \\
\hline & $\begin{array}{c}\text { Oral } \\
\text { contraceptive } \\
\text { s pills }\end{array}$ & 124 & $10.14 \%$ \\
\hline & IUCD interval & 167 & $13.65 \%$ \\
\hline & $\begin{array}{l}\text { Post placental } \\
\text { IUCD }\end{array}$ & 54 & $4.42 \%$ \\
\hline & Tubectomy & 226 & $18.46 \%$ \\
\hline & $\begin{array}{l}\text { Natural } \\
\text { methods }\end{array}$ & 08 & $.68 \%$ \\
\hline \multirow{4}{*}{$\begin{array}{c}\text { Criteria for } \\
\text { choice of the } \\
\text { method* }(n= \\
1225)\end{array}$} & $\begin{array}{l}\text { Completed } \\
\text { their families }\end{array}$ & 228 & $18.26 \%$ \\
\hline & $\begin{array}{l}\text { Spacing of } \\
\text { birth }\end{array}$ & 959 & $78.28 \%$ \\
\hline & $\begin{array}{l}\text { Improvement } \\
\text { of health }\end{array}$ & 38 & $3.09 \%$ \\
\hline & $\begin{array}{c}\text { Economical } \\
\text { problems }\end{array}$ & 00 & 00 \\
\hline \multirow{2}{*}{$\begin{array}{l}\text { Discontinuatio } \\
n \text { of } \\
\text { contraceptive } \\
\text { method in user } \\
(\mathrm{n}=1225)\end{array}$} & Yes & 49 & $4 \%$ \\
\hline & No & 1176 & $96 \%$ \\
\hline & Distributi & $\begin{array}{l}\text { ractices } \\
\text { lods }\end{array}$ & \\
\hline
\end{tabular}




\begin{tabular}{|c|c|c|c|}
\hline & Reasons & $\begin{array}{c}\text { No. of } \\
\text { Women }\end{array}$ & $\begin{array}{c}\text { Percentage } \\
\text { (\%) }\end{array}$ \\
\hline \multirow{8}{*}{$\begin{array}{l}\text { Reason for } \\
\text { discontinuation } \\
\text { of IUDs } \\
n=33\end{array}$} & $\begin{array}{l}\text { Want male } \\
\text { child }\end{array}$ & 6 & $18.18 \%$ \\
\hline & $\begin{array}{l}\text { Want female } \\
\text { child }\end{array}$ & 3 & $9.09 \%$ \\
\hline & Bleeding & 6 & $18.18 \%$ \\
\hline & Back pain & 7 & $21.21 \%$ \\
\hline & $\begin{array}{c}\text { White } \\
\text { discharge }\end{array}$ & 5 & $15.15 \%$ \\
\hline & $\begin{array}{l}\text { Abdominal } \\
\text { pain }\end{array}$ & 2 & $6.06 \%$ \\
\hline & $\begin{array}{l}\text { Spontaneous } \\
\text { expulsion }\end{array}$ & 2 & $6.06 \%$ \\
\hline & Failure & 2 & $6.06 \%$ \\
\hline \multirow{7}{*}{$\begin{array}{c}\text { Reason for } \\
\text { discontinuation } \\
\text { of oral } \\
\text { contraceptives } \\
\text { pills } \\
\mathrm{N}=16\end{array}$} & Headache & 1 & $6.25 \%$ \\
\hline & $\begin{array}{l}\text { Forget to } \\
\text { take }\end{array}$ & 1 & $6.25 \%$ \\
\hline & $\begin{array}{l}\text { Irregular } \\
\text { bleeding }\end{array}$ & 1 & $6.25 \%$ \\
\hline & $\begin{array}{c}\text { Failure of } \\
\text { contraceptive }\end{array}$ & 1 & $6.25 \%$ \\
\hline & No reason & 5 & $31.25 \%$ \\
\hline & $\begin{array}{c}\text { Want male } \\
\text { child }\end{array}$ & 3 & $18.75 \%$ \\
\hline & $\begin{array}{l}\text { Want female } \\
\text { child }\end{array}$ & 4 & $25 \%$ \\
\hline Total & & 49 & $4 \%$ \\
\hline
\end{tabular}

\begin{tabular}{|c|c|c|}
\hline No. of Women's & No. of Cases & $\begin{array}{c}\text { Percentage } \\
\text { (\%) }\end{array}$ \\
\hline Want child female & 338 & $17.11 \%$ \\
\hline Want child male & 668 & $33.28 \%$ \\
\hline Rumoured side effects & 344 & $17.41 \%$ \\
\hline No guidance & 117 & $5.92 \%$ \\
\hline $\begin{array}{c}\text { Opposition from } \\
\text { home }\end{array}$ & 89 & $4.51 \%$ \\
\hline Breast feeding & 96 & $4.86 \%$ \\
\hline Hysterectomy & 64 & $3.24 \%$ \\
\hline Not having sex & 74 & $3.74 \%$ \\
\hline No knowledge & 43 & $2.17 \%$ \\
\hline Menopausal & 13 & $.65 \%$ \\
\hline Religion & 39 & $1.97 \%$ \\
\hline $\begin{array}{c}\text { No knowledge about } \\
\text { source }\end{array}$ & 28 & $1.42 \%$ \\
\hline Hesitancy & 48 & $2.44 \%$ \\
\hline Total & 1975(61.71\%) & $\mathbf{1 0 0 \%}$ \\
\hline $\begin{array}{c}\text { Table 9: Distribution of respondents according to } \\
\text { Reasons for not accepting family Planning methods }\end{array}$ \\
\hline \multicolumn{2}{|c}{}
\end{tabular}

\section{REFERENCES}

1. Park K. Demography and family planning. In; Park K textbook of preventive and social medicine. $22^{\text {nd }}$ edition M/S Banarsidas Bhanot publishers 2013.

2. Govt. of India (2012), census 2011, provisional population report, office of the registrar general and census commissioner India, Ministry of Home Affairs, March 31st, 2011.

3. National Family Health Survey NFHS-2. India 1998-99 International Institute for Population Sciences, Mumbai, India measure DHS +ORS \& MACRO.

4. National Family Health Survey NFHS -3. India 2005-06 International Institute for Population Science, Mumbai, India measure DHS+ORS \& MACRO.

5. http://mohfw.nic.in/WriteRead Data/1892s/972971120 FW\% 20 Statistics\% 2020 11\% 20 Revised \% 2031\% 2010\%2011.pdf.

6. WHO (1999) Health situation in the South East Asia region 1994-1997, regional office of SEAR, New Delhi.

7. "Size growth rate and distribution of population" http://www.censusindia.gov.in/2011.

8. Mitali G Patel1, Darshan K. Mahyavanshi1, Girija Kartha2, Shyamal K Purani2, Sunita S. A cross-sectional study on knowledge, attitude and practice regarding spacing methods among married women of the reproductive age group in the field practice area of UHTC in Surendranagar district Volume 2 Issue 2 July-December 2011.

9. Mustafa R, Afreen U, Hashmi HA. Karachi knowledge, attitude regarding family planning and the practice of contraceptives among rural women. Journal of the College of Physicians and Surgeons Pakistan 2008, Vol. 18(9):542-54.

10. Saluja N, Sharma S, Choudhary S, et al.: Contraceptive Knowledge, Attitude and Practice among Eligible Couples of Rural Haryana. The Internet Journal of Health. 2011 Volume 12 Number 1. DOI:10.5580/156e.

11. Lwelamira J, 1 Mnyamagola G and Msaki2 MM. Knowledge, Attitude and Practice (KAP) towards Modern Contraceptives Among Married Women of Reproductive Age in Mpwapwa District, Central Tanzania 2014.

12. International Institute of Population Sciences IIPS, 2010. District level household and fertility servayn DLSH 3 2007n-08; India, Madhya Pradesh; Mumbai; IIPS.

13. Takkar N, Goel P, Dua D. Contraceptive practices and awareness of emergency contraception in educated working women. Indian J Med Sci 2005;59:143-149.

14. SREYTOUCH1 Knowledge, Attitude and Practice (KAP) of Family Planning among Married Women in Banteay Meanchey, Cambodia 2011.

15. Sajid A, Malik S. Knowledge, Attitude and Practice of Contraception among multiparous women at Lady Aitchison Hospital, Lahore, ANNALS VOL 16. NO. 4 OCT. - DEC. 2010.

16. Jain S, Singh JV, Bhatnagar M, Garg SK, Chopra H, Bajpai SK. Attitude of rural women towards contraceptive and its use. Indian J Matern Child Health. 1999; JanMar10(1):18-9.

17. Kumar R, Singh MM, Kaur M. Dynamics of contraceptive use in rural community of Haryana. Indian J Med Sci 1999;53(5):201-11.

18. Chandhick N, Dhillon BS, Kambo I, et al. Contraceptive knowledge, practices and utilisation of services in rural areas of India (an ICMR task force study). Indian J Med Sci 2003;57(7):303-10.

19. Srivastava Reena, Srivastava Dhirendra Kumar, Jina Radha, Srivastava Kumkum, Sharma Neela, Saha Sushmita. Obstet Gynecol India Vol. 55, No. 6: November/December 2005 Pg. 546-550. 
20. Kaushal SK, Saxena SC, Srivastava VK. KAP study on contraceptive methods in Kanpur District of UP 2005 Volume 21 Number 2 Volume 22 Number 1 July20092012.

21. Patro BK, Kant S, Baridalyne N, et al. Contraceptive practices among married women in a resettlement colony of Delhi. Health and Population - Perspectives and Issues. 2005;28(1):9-16.

22. Mao J: Knowledge, Attitude and Practice of Family Planning: A Study of Tezu Village, Manipur (India). The Internet Journal of Biological Anthropology. 2007 Volume 1 Number 1. DOI: $10.5580 / 3 \mathrm{cc}$.

23. Roumi Deb. Knowledge, Attitude and Practices related to Family Planning Methods among the Khasi Tribes of East Khasi Hills, Meghalaya Anthropologist, 12(1):4145(2010).

24. Velankar H Deepa. Knowledge, Attitude and Practices regarding contraceptive methods of family planning in an urban slum community of Mumbai. Bombay Hospital Journal, VoL 51, No. 2, 2009:p149-154.

25. Mgabo RM, Mugane JLB and Lwelamira J 2010. Community knowledge perception and practices towards Bilharzia infection and related programs in Maisome Island in Sengerema District, Mwanza, Tanzania. Rural Plann J Vol. 12.

26. Gaur DR, Goel MK, Goel M. Contraceptive practices and related factors among females in predominantly rural Muslim Area of North India. The Internet J of World Health and Societal Politics, 2008;5(1).

27. Kansal A, Chandra R, Kandpal SD, et al. "Epidemiological correlates of contraceptive prevalence in rural population of Dehradun District." Indian J of Community Medicine, 2005; Vol 30(2):60-62.

28. Martin TC and Juanej F. The impact of women education on fertility in Latin America; searching for explanation, international family planning perspectives, 21 2;52-57 and 80, 1995.

29. Khokhar A, Mehra M. Contraceptive use in women from resettlement area in Delhi. Indian J Comm Med 2005; Mar:30.

30. Khokhar A, Gulati N. A study of never users of contraception from an urban slum of Delhi. Indian J Comm Med 2000; Jan-Mar: 25(1).
31. Tuloro T, Wakgari D, Ahmed A, et al. 2006. The role of men in contraceptive use and fertility preference in Hossana Town, Southern Ethiopia Ethiopian J. Health Dev., 20(3):152-159.

32. Nwankwo BO and Ogueri E 2006. Influence of husband's decision on the use of modern contraceptives among rural and urban married women in Omo State, Nigeria. Int J Trop Med 1(4):140-144.

33. Igwegbe A, Ugboaja J and Monago E, 2009. Prevalence and determinants of unmet need for family planning in Nnewi, South-East Nigeria. Int J Medic Med Sci 1(8):325329.

34. Burke HM and Ambasa-Shisanya C, 2011. Qualitative study of reasons for discontinuation of injectable contraceptives among users and salient reference groups in Kenya. Afr J Reprod Health, 15(2):67-78.

35. Mathe JK, Kasonia KK and Maliro AK 2011. Barriers to adoption of family planning among women in eastern democratic republic of Congo. Afr J Reprod Health, 15(1):69-77.

36. Prachi R, Das GS, Ankur B, et al. A study of knowledge, attitude and practice of family planning among the women of reproductive age group in Sikkim. J Obstet Gynecol. 2008;58:63-7.

37. Srivastava R, Srivastava DK, Jina R, Srivastava K, Sharma N, Sana S. Contraceptive knowledge, attitude and practice (KAP Survey). J Obstet Gynecol. 2005;55:54650.

38. Das R, Amir A, Nath P. Utilisation and coverage of services by women of Jawan Block in Aligarh. Indian J Comm Med 2001; Apr-Jun: 26(2).

39. Vaidya VG, Sahasrabudhe BG, Jogi JA, et al. Profile of sterilized women in urban slums and evaluation of motivational strategies. Indian J Public Health. 2003; JanMar 47(1):31-3.

40. Khokhar A, Gulati N. A study of never users of contraception from an urban slum of Delhi. Indian J Comm Med. 2000; Jan-Mar: 25(1).

41. Anju P, Suneeta G, Mehra M. Assessment of Unmet Need for Contraception in an urban slum of Delhi. Indian J Comm Med. 2004; Jul-Sept: 29(3). 